Canadian

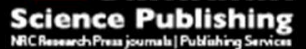

Canadian Journal of Civil Engineering Revue canadienne de génie civil

\title{
Maximum acceptable concentration levels of the chemical agent sarin in Canadian and Russian soil types
}

\begin{tabular}{|r|l|}
\hline Journal: & Canadian Journal of Civil Engineering \\
\hline Manuscript ID & cjce-2015-0279.R1 \\
\hline Manuscript Type: & Article \\
\hline Date Submitted by the Author: & 02-May-2016 \\
\hline Kemplete List of Authors: & $\begin{array}{l}\text { Maslennikov, Alexander; RIHTOP, } \\
\text { Filatov, Boris; RIHTOP, } \\
\text { Demidova, Svetlana; RIHTO, } \\
\text { Samuleev, Pavel; Royal Military College of Canada, Chemistry and } \\
\text { Chemical Engineering } \\
\text { Creber, Katherine; Royal Military College of Canada, Chemistry and } \\
\text { Chemical Engineering } \\
\text { Andrews, William; Royal Military College of Canada, Chemistry and } \\
\text { Chemical Engineering }\end{array}$ \\
\hline Keyword & $\begin{array}{l}\text { sarin, chemical warfare agent, soil contamination, no observed effect } \\
\text { concentration (NOEC), soil toxicology }\end{array}$ \\
\hline
\end{tabular}




\title{
Maximum acceptable concentration levels of the chemical agent sarin in Canadian and Russian soil types
}

\author{
Alexander A. Maslennikov, ${ }^{\text {a }}$ Boris N. Filatov, ${ }^{\text {a }}$ Svetlana A. Demidova, ${ }^{\text {a }}$ Pavel V. Samuleev, \\ Katherine A.M. Creber, ${ }^{b}$ William S. Andrews ${ }^{b^{*}}$
}

\author{
${ }^{a}$ Research Institute of Hygiene, Toxicology and Occupational Pathology at the Federal Medical and \\ Biological Agency, Volgograd, Russia \\ ${ }^{b}$ Department of Chemistry and Chemical Engineering, Royal Military College of Canada, Kingston \\ ON, Canada K7K 7B4 \\ *corresponding author \\ phone: +1 6135416000 x 6052, fax: +1 613542 9489, email: andrews-w@rmc.ca
}

word count 6771 
Abstract: The lowest-observed-adverse-effect and no-observed-adverse-effect (NOAEC) concentrations of sarin were determined in soils typical to Canada and Russia. Maximum acceptable concentrations (NOAEC) were established to be $3.0 \times 10^{-4} \mathrm{mg} \mathrm{kg}^{-1}$ for the standard reference soil, $2.0 \times 10^{-3} \mathrm{mg} \mathrm{kg}^{-1}$ for prairie soil and $1.0 \times 10^{-2} \mathrm{mg} \mathrm{kg}^{-1}$ for forest soil.

Keywords: sarin, chemical warfare agent, soil contamination, no observed effect concentration (NOEC), soil toxicology

Résumé: Les concentrations (lowest-observed-adverse-effect and no-observed-adverse-effect) maximales de sarin sont déterminées pour des sols typiques au Canada et à la Russie. Les concentrations maximales de sarin acceptables ont été établies comme $3.0 \times 10^{-4} \mathrm{mg} \mathrm{kg}^{-1}$ pour le sol de référence, $2.0 \times 10^{-3} \mathrm{mg} \mathrm{kg}^{-1}$ pour le sol de prairie et $1.0 \times 10^{-2} \mathrm{mg} \mathrm{kg}^{-1}$ pour le sol de forêt.

Mots-clés: sarin, agent de guerre chimique, contamination de sol, concentration avec aucun effet observé, toxicologie de sol 


\section{Introduction}

In 20 March 1995, at about 7 AM local time, the chemical warfare agent (CWA) sarin (Oethyl-S-(2-diisoproylaminoethyl) methyl phosphonothiolate), was used in a terrorist attack at a Tokyo subway station. This agent was also reportedly used in Syria in and around Damascus (Ghouta) on 21 August 2013. Sarin (also known as GB) is a non-persistent nerve agent that was developed in the late 1930s in Germany and was weaponized by both sides of the cold war, among other nations. The Chemical Weapons Convention (CWC), with Syria becoming the $190^{\text {th }}$ member state to sign on, monitors and controls the production, storage and use of CWAs for research and training purposes. This, however, as noted above, has not prevented their unauthorized use (OPCW 2015, UN 2013). This paper examines the acceptable levels of sarin in three different types of soils, with a view to establishing acceptable clearance levels after an accidental or deliberate release of the agent.

Soil was chosen as the medium of study, as it is a living system in which biological, biochemical and physical-chemical processes occur. As such, it is an essential habitat that supports life on the surface of the Earth. Due to its extremely complex structure, this biological environment not only accumulates exogenous contaminants, but can contribute to their migration into the air and water reservoirs (Sadovnikova 2006, Pavlov 2005, Mineev and Rempe 1990, Shilov 2006, Isidorov 2001, Strelnikov 2004 and Korolev 2001). Moreover, toxic substances in the ground can interact with communities of microorganisms, which can lead to microbiome, or the suppression and appearance of new forms of pathogenic bacteria (Sadovnikova 2006, Egorenkov and Kochurov 2005, Revazova 2000, Serikoff 1992, 1994, Egorova and Belolipetskaya 2000). Plants growing on the contaminated substrate absorb and accumulate exogenous chemicals, and, when eaten, may cause negative effects on humans and animals (Sadovnikova 2006, Mineev and Rempe 1990, Protasov 2005, Hotuntsev 2004, Slodkopevtsev 2005, Green et al 1979, Melnikov et al., 1977).

Highly toxic substances represent a significant threat to the normal functioning of the ecosystem. As a result, the latter's self-purification ability and biological activity become violated 
(Kruglov 1991, Mishustin et al. 1979, and Yudanova 1989). This problem is particularly relevant in relation to the implementation of the destruction of chemical weapons, performed in accordance with international conventions (Chemical weapons 1996, Agadzhanov 1993, and Guidelines 1982). In addition, in recent years the cases of threats of terrorist attacks using poisonous substances have become more frequent all over the world. These hazardous substances can be used not only against humans, but also for environmental deterioration and degradation. Negative environmental effects are also possible in the case of industrial accidents.

The purpose of this paper is to report on an experimental study to determine lowestobserved-adverse-effect (LOAEC) and no-observed-adverse-effect (NOAEC) concentrations of sarin in three different types of soil.

As suggested above, sarin is an extremely toxic substance (for respiratory exposure, the lethal concentration for $50 \%$ of the population, or $\mathrm{LCt}_{50}$, is $100 \mathrm{mg}-\mathrm{min}^{-3}$, and for dermal exposure, the lethal dose or $\mathrm{LD}_{50}$ is $1700 \mathrm{mg}$ ) (Medscape 2015). Sarin is tightly controlled by the CWC, which extends to both storage and, when needed, synthesis. For both these reasons, only a very limited number of tests were possible, so that the usual statistical rigour was not able to be exercised, e.g., a statistically significant number of replicates were not examined. That said, facilities handling CWAs must be licensed by national authorities and registered with the Organization for the Prohibition of Chemical Weapons, or OPCW, who administer the CWC and conduct on-site inspections (OPCW 2015). For all these reasons, the experimental work reported upon here has been challenging to get approved to conduct and then to proceed with the extremely limited amount of agent available. The results below, nonetheless, fill an important gap in knowledge that could prove invaluable in addressing cleanup following the inadvertent or illegallyplanned release of this substance.

Work was performed under a contract with the International Science and Technology Center (ISTC, Moscow) in collaboration with the Royal Military College of Canada, with financial support from the Government of Canada (Department of Foreign Affairs, Trade and Development). 


\section{Materials and Methods}

O-ethyl-S-(2-diisoproylaminoethyl) methyl phosphonothiolate (sarin) of 95\% purity obtained from the Federal State Unitary Enterprise "State Research Institute of Organic Chemistry and Technology" (GosNIIOKhT) was used in the study. Pit sand collected from a depth of at least 3 $\mathrm{m}$ from the ground surface was used as the standard reference soil (SRS), due to its maximum filtration and minimal sorption abilities, neutral $\mathrm{pH}$ and low organic carbon content (Guidelines 1982 and Goncharuk and Sidorenko 1986 ).

In addition to this, types of soils were chosen in the Russian Federation which were also good models for soils of the prairies and mixed forests in Canada. Based on the physical-chemical characteristics, soil from the steppe zone of the Lower Volga (PSM) was chosen as the analogue for Canadian prairie soil, while forest soil from the Republic of Udmurtia (FSM) was chosen as the analogue Canadian forest soil. Soil characteristics are presented in Table 1 (Lobova and Khabarov 1983 and Kaurichev 1982).

Experimental justification of the safe levels of sarin in these soils was carried out in accordance with Russian Federation Guidelines (1982). To conduct experimental studies on the toxic effects of an exogenous substance on soil microflora, the processes of nitrification and phosphorus exchange, it is necessary to create a soil mixture (SM), with certain characteristics. Our SMs were created from the forest or steppe soils and sand in such a way that the total organic carbon measured by Turin's method did not exceed $0.5 \%$, and microbiome was as close as possible to the one observed in the rendzina of the deciduous and coniferous forests and prairie soils of Canada.

The necessary physical and chemical properties of soil models (Tables A1-A3) were measured before the experiments by the following methods. The diameter of the soil particles was measured by the Kaczynski-Fedulov technique with Knopp's sieves (Goncharuk and Sidorenko 1986 and 
Kaurichev 1990). Full moisture capacity was estimated by drying to a constant weight (Guidelines 1982, Goncharuk and Sidorenko 1986 and Kaurichev 1990). The organic carbon content was determined by Turin's method and was done spectrophotometrically with the oxidation of organic compounds in soil by potassium dichromate (Mineev 2001). The $\mathrm{pH}$ of the aqueous extracts of soil samples, redox potential, exchange acidity, hydrolytic acidity and hydrolytic alkalinity were measured potentiometrically (Guidelines 1982, Goncharuk and Sidorenko 1986, Kaurichev 1990 and Mineev 2001). Spectrophotometric analysis was used to measure soluble phosphates. Nitrogen in ammonium was determined spectrophotometrically by reaction with Nessler's reagent, and in nitrites and nitrates by reaction with $\alpha$-naphthylamine/sulfanilic acid and sodium salicylate, respectively (Mineev 2001). Finally, the density of the solid phase of the soil was determined by Kaurichev's method (Kaurichev 1990).

Soil mixtures were also analyzed for the presence of the main background microflora such as saprophytic bacteria, E.Coli, fungi and actinomycetes. Concentrations of sarin used in different experiments are summarized in Table A4. Mixtures of the model soils and standard reference soil in fixed ratios were used to study the soils' self-cleaning ability and microbiome (Guidelines, 1982 and Goncharuk and Sidorenko 1986).

\section{Extraction of sarin with water}

The aim of the research was to determine the permissible level of sarin in the soils by measuring its concentration in the water passed through 1 meter of contaminated soil. Sarin concentration in such waters should not exceed 5.0 $\times 10^{-5} \mathrm{mg} \mathrm{L}^{-1}$ (Guidelines 1982 and Goncharuk and Sidorenko 1986). One-meter-high fiberglass columns with a cross sectional area of $100 \mathrm{~cm}^{2}$ were used for the experiments. In accordance with the customary practice in Russia, each column was charged with an SRS of $60 \%$ humidity. Sarin solutions (with concentrations given in Table A4) were spread evenly in the upper dry layer (1 kg) of soil (SRS, FSM, PSM) and then the soil was washed with water. Three times a day, $32 \mathrm{~mL}$ of dechlorinated settled water was added to the 
column. This amount was calculated based on the duration of the experiment (one month) and the mean annual precipitation in the geographic area of the corresponding type of soil (Guidelines 1982 and Goncharuk and Sidorenko 1986). Sampling of the seepage water was also carried out fractionally, three times a day, 30 min after column irrigation. Samples were combined at the end of the day, and the toxicant was extracted and its concentration was measured by gas-chromatography (Methodological guidelines 2004). Each experiment was performed in triplicate and average results were reported.

\section{Migration of sarin into air}

The ability of sarin to migrate into the air from SRS, FSM and PSM was studied by measuring its concentration above the soil surface in a $100 \mathrm{dm}^{3}$ sealed chamber equipped with both a sampling device and an air ventilation rate adjuster. Following Russian Federation standards, the concentration of sarin in workspace air should not exceed $2.0 \times 10^{-5} \mathrm{mg} \mathrm{m}^{-3}$. ( The corresponding value from the Center for Disease Control/National Institute for Occupational Safety and Health (NIOSH)_ in the United States is $3.0 \times 10^{-5} \mathrm{mg} \mathrm{m}^{-3}$ for workers over an 8-hour work shift. CDC 2015). Sarin was evenly distributed in the model soil by dissolving a given amount in an experimentally-established volume of distilled water $(128 \mathrm{~mL})$ needed to wet $1 \mathrm{~kg}$ of soil up to $60 \%$ of its maximum water-absorption capacity. The resulting mixture was stirred thoroughly and placed in a crystallization bowl $(200 \times 150 \mathrm{~mm})$ in a sealed chamber with a constant temperature of $28^{\circ} \mathrm{C}$ and humidity of $60-70 \%$ (which simulates summer conditions when sarin evaporates most readily from the soil surface). Air sampling was performed by passing air from the chamber at the rate 1 $\mathrm{L} / \mathrm{min}$ for $15 \mathrm{~min}$ through an absorber filled with $5 \mathrm{~mL}$ of distilled water having a $\mathrm{pH}$ of 7.2 and porous plate \#1. Sarin presence in the resulting solution was detected by reaction with propionylcholinesterase (State Research Institute 2005).

Sarin has the highest volatility among chemical warfare agents - $12.0 \mathrm{mg} \mathrm{L}^{-1}$ (Methodological guidelines 2004). Therefore, air sampling was performed, on the first day of the 
experiment, $1 \mathrm{~h}$ after soil contamination and then twice more every hour, and on the second day at 10 AM.

Each experiment was performed and triplicate and average results were reported.

\section{Microbiological experiments}

The ability of soils contaminated with sarin to self-purify and restore microbial activity was evaluated by counting the number of colonies of viable microorganisms involved in the recovery and purification of the soil and changes in the intensity of the biochemical processes (nitrification).

To study general health hazards, soil mixtures (SM) of FSM (33.3\%) and PSM (20\%) with SRS were used. The low content of organic matter in soil, e.g., the presence of soil carbon less than $0.5 \%$, led to small amounts of soil microorganisms, minerals and enzymes, creating low sensitivity conditions for exposure to sarin.

To find microorganisms in the soil that have selective sensitivity to sarin, different groups of soil microbiome were studied. Saprophyte bacteria - the most numerous and active group of microflora, were studied on soil agar. Mushrooms (micromycetes), filamentous bacteria (actinomycetales), and Escherichia coli, characterizing the degree of contamination of the soil, were studied on the Chapek medium, starch-ammonia agar and Endo agar, respectively (Guidelines 1982, Goncharuk and Sidorenko 1986, Franke et al. 1967, Guidance 1976, Zvyagintsev 1980 and Babeva and Zenova 1989).

Microorganisms (bacteria, micromycetes and actinomycetes) from the soil mixtures, diluted from 10 to 10000 times in sterile tap water, were seeded on Petri dishes by a dropwise method for bacteria and actinomycetes and by a spread plating technique for fungi (Guidance 1976, Zvyagintsev 1980 and Babeva and Zenova 1989). Microbiological sampling and seeding from soil mixtures were performed in triplicate on the 0 -th, 1 st, $3 \mathrm{rd}, 7 \mathrm{th}, 10$ th and 14 th day from the moment of contamination (Guidelines 1982, Goncharuk and Sidorenko 1986 and Guidance 1976). Fungi, 
actinomycetes and saprophytic bacteria were incubated in the dry-air oven at $24-26{ }^{\circ} \mathrm{C} ;$ E. coli - at $37^{\circ} \mathrm{C}$ (Guidance 1976, Zvyagintsev 1980 and Babeva and Zenova 1989).

Sarin toxic effects on the soil microbial community have been evaluated as an average total number of colonies of microorganisms. Significant results were defined as those differing more than $50 \%$ from controls. The dynamics of biochemical processes were assessed by the content of ammonia, nitrite and nitrate ions (Guidelines 1982, Goncharuk and Sidorenko 1986, Lobova and Khabarov 1983, Kaurichev 1982, 1990 and Mineev 2001 and Babeva and Zenova 1989). The experiments were performed at room temperature $\left(20-25^{\circ} \mathrm{C}\right)$ and $60 \%$ humidity of PSM and FSM samples. Containers with samples studied were kept in the dark.

The following timeframe was used to perform soil sample analysis. On the day of contamination, control background samples were analyzed. On the $1,3,7,10$ and $14^{\text {th }}$ days, contaminated and control soil samples were analyzed. Main indicators of the nitrification process were as described above. Significant results were defined as those that differ more than $25 \%$ from the control experiments within 14 days of observation.

For sarin's phytotoxicity study in the SRS, PSM and FSM soils, seeds from crops widely represented in the human diet, such as cereals (wheat), root vegetables (beets), legumes (beans) and vegetables (zucchini), were used (Guidelines 1982 and Goncharuk and Sidorenko 1986). All seeds of the test plants had certificates of quality.

Seed germination under the influence of the toxicant was studied by placing an equal number of seeds (10 pieces) on moist contaminated and uncontaminated soils (SRS, PSM, FSM) in Petri dishes for 3 days. Seeds were covered with filter paper on both sides. Germination was determined based on the appearance of sprouts in comparison to the controls.

The effect of the toxicant on plants' root growth was evaluated in the soils of interest (SRS, PSM, FSM) by placing $50 \mathrm{~g}$ of soil into a Petri dish with the addition of $0.1 \mathrm{~mL}$ of a Pryanishnikov's nutrition mixture (to improve the plants' living conditions) and brought to full moisture capacity by adding a water solution of sarin of a given concentration (Guidelines 1982 and 
Goncharuk and Sidorenko 1986). The soil was then covered with a filter paper and 10 plant seeds were placed in each cup. Seeds were then covered with another piece of dry filter paper. After that, closed Petri dishes were placed in the incubator for 14 days at a temperature of $23{ }^{\circ} \mathrm{C}$ and a relative humidity of $50-70 \%$. During the experiment, constant soil moisture was maintained in the Petri dishes.

Phytotoxic effects were determined by changes in the root growth of seeds germinated on the substrate. Root lengths were measured 3, 7, 10 and 14 days after toxicant addition to the soil. The overall appearance of the roots (color, shape, branching) was recorded as well.

The following criteria were considered while choosing plants for the vegetation experiments: low sensitivity to the toxicant's effects on seed germination; belonging to the cereal family, which allow determination of growth and development of the stem; possible depigmentation; and the green mass of the plants (haulm cut directly before measurement). Based on the results of preliminary experiments of the sarin toxic effects assessment on the germination of seeds, wheat met the above mentioned requirements and was chosen for these tests.

To determine threshold and no observed effect concentrations (NOECs) of sarin on the growth of the plants, three plant seeds were planted into $4.0 \times 4.0 \times 7.0 \mathrm{~cm}$ containers containing $80.0 \mathrm{~g}$ of PSM or FSM soil. Then, the substance, dissolved in dechlorinated settled water, was introduced into the system. Controls were performed using settled dechlorinated water without sarin. Trays with containers were kept in a climatic chamber MLR-351H (Sanyo) at temperatures ranging from $17-28{ }^{\circ} \mathrm{C}$ and relative humidities of $65-80 \%$, depending on the time of the day.

The toxic effects of the substance were determined by changes in the growth of the stems, possible depigmentation, and sprout development (deformation, branching). These parameters were registered on the $3^{\text {rd }}, 7^{\text {th }}, 10^{\text {th }}$ and $14^{\text {th }}$ days after soil contamination. The mass of the green part of the plant was determined after exposure. Results were considered meaningful if values were more than 20\% different from the control value (Guidelines 1982 and Goncharuk and Sidorenko 1986). 


\section{Results and Discussion}

\section{Standard Reference Soil}

During the study of sarin migration in soil with water it was shown that sarin's residence time in soil is proportional to its concentration. It was found that at the initial concentration of sarin, $4.0 \times 10^{-4} \mathrm{mg} \mathrm{kg}^{-1}$, agent was leached from the soil in the period from the $5^{\text {th }}$ to the $15^{\text {th }}$ day of the experiment, with the maximum on the $10^{\text {th }}$ day $\left(5.6 \times 10^{-5} \mathrm{mg} \mathrm{L}^{-1}\right)$. On the other hand, a lower initial sarin concentration $\left(3.0 \times 10^{-4} \mathrm{mg} \mathrm{kg}^{-1}\right)$ led to longer agent residence time in the soil. It was washed out from the $9^{\text {th }}$ to the $11^{\text {th }}$ day, with concentrations below the occupational exposure limit for drinking water. Based on the results above, the lowest significant dose for migration in water was $4 \times 10^{-4} \mathrm{mg} \mathrm{kg}^{-1}$, while the permissible level not exceeding the occupational exposure limit was $3.0 \times 10^{-4} \mathrm{mg} \mathrm{kg}^{-1}$.

Study of sarin migration in air has shown that agent evaporates from the surface within the first hour after contamination, independent of the initial concentration. The LOAEC of the agent was $5.0 \times 10^{-3} \mathrm{mg} \mathrm{kg}^{-1}$. On the other hand, the concentration of sarin in air did not exceed the occupational exposure limit for air $\left(3 \times 10^{-5} \mathrm{mg} \mathrm{m}^{-3}\right.$ for the short term exposure limit) (OSHA 2015) when the initial contaminant concentration was $2.0 \times 10^{-3} \mathrm{mg} \mathrm{kg}^{-1}$. Therefore this concentration was used as the NOAEC for standard reference soil.

It was found that sarin had a negative effect on the germination of all seeds tested at the concentration of $10 \mathrm{mg} / \mathrm{kg}$. At the lower sarin concentration of $1 \mathrm{mg} / \mathrm{kg}$, negative germination effect was observed for all seeds but zucchini. And, finally, at the lowest concentration of $0.1 \mathrm{mg} / \mathrm{kg}$, only the germination of beet seeds was affected, which represents its sensitivity towards the studied organophosphorus compound.

Based on sensitivity toward sarin toxicity, plant seeds can be placed in the following order: beets $>$ beans $>$ wheat $>$ zucchini. As zucchini seeds were not very sensitive to the sarin concentration in soil they were excluded from further study. 
A study of sarin phytotoxic properties has shown its negative impact on higher plants. The minimal effective concentration of sarin on seed germination was $0.1 \mathrm{mg} \mathrm{kg}^{-1}$. The impact of chemical agent on plant root systems was assessed and the LOAEC and NOAEC concentrations were found to be $2.5 \times 10^{-2}$ and $1.0 \times 10^{-2} \mathrm{mg} \mathrm{kg}^{-1}$ respectively (determined from triplicates). Based on all the above, the limiting hazard index (or lowest concentration for which effects were detected) for sarin was its migration in water, which was found to be $3.0 \times 10^{-4} \mathrm{mg} \mathrm{kg}^{-1}$ (Table 2).

\section{Prairie Soil Model}

Our studies showed that sarin does not migrate with water in the prairie soil model, due to its poor water permeability. Therefore, the hazard index for migration in water was not defined and a subthreshold level was set as $0.1 \mathrm{mg} \mathrm{kg}^{-1}$ - the highest concentration of the agent used. The concentrations used in this determination are contained in Table A4, with all tests conducted in triplicate.

The study of sarin migration in air has shown that agent evaporates from the soil surface only within the first hour after contamination. The LOAEC of the agent was $0.1 \mathrm{mg} \mathrm{kg}^{-1}$ and maximum NOAEC was found to be $5.0 \times 10^{-2} \mathrm{mg} \mathrm{kg}^{-1}$.

Analysis of the results of the general health hazard of contaminated soil showed that nitrifying bacteria were the most sensitive to negative sarin effects. LOAEC and NOAEC were 0.1 and $5.0 \times 10^{-2} \mathrm{mg} \mathrm{kg}^{-1}$, respectively, for microbiome and, correspondingly, $5.0 \times 10^{-3}$ and $2.0 \times 10^{-3} \mathrm{mg}$ $\mathrm{kg}^{-1}$ for nitrification. Therefore, the maximum permissible concentration of sarin in PSM, based on the general health hazard, was $2.0 \times 10^{-3} \mathrm{mg} \mathrm{kg}^{-1}$.

It was shown that sarin introduced into PSM in the concentrations $2.0 \times 10^{-3}, 1.0 \times 10^{-2}$ and $5.0 \times 10^{-2} \mathrm{mg} \mathrm{kg}^{-1}$ did not affect seed germination, using triplicates in each case. Therefore $5.0 \times 10^{-2}$ $\mathrm{mg} \mathrm{kg}{ }^{-1}$ was chosen as the NOAEC. 
At the same time, the toxicant showed a negative effect on the root systems of higher plants, significantly slowing growth and development. The $21 \%$ decrease of wheat roots growth was observed on the $3^{\text {rd }}$ day of growth at the sarin concentration $0.05 \mathrm{mg} / \mathrm{kg}$. Zucchini root growth was decreased by $27 \%$ on the $7^{\text {th }}$ day of growth at $0.01 \mathrm{mg}$ of sarin per $\mathrm{kg}$ of PSM soil. At concentrations below $0.002 \mathrm{mg} / \mathrm{kg}$, no effects of sarin were observed on root system development of all plant seeds tested.

Plants can be distributed in the following order based on it root system development sensitivity towards sarin in PSM soil: wheat $>$ zucchini $>$ beets $>$ beans. The LOAEC and NOAEC of the agent were found to be $1.0 \times 10^{-2} \mathrm{mg} \mathrm{kg}^{-1}$ and $2.0 \times 10^{-3} \mathrm{mg} \mathrm{kg}^{-1}$, respectively.

Vegetation experiments have shown that sarin had a negative influence on the growth of wheat stalks, but did not affect the green part mass (haulm cut directly before measurement). LOAEC and NOAEC values were 0.45 and $0.15 \mathrm{mg} \mathrm{kg}^{-1}$, respectively.

Based on the most sensitive value above, i.e., the NOAEC for root systems, the exposure limit for sarin in the prairie soil model was found to be $2.0 \times 10^{-3} \mathrm{mg} \mathrm{kg}^{-1}$ (Table 3).

\section{Forest Model Soil}

Three different concentrations of sarin were used to study the migration of the agent with water in the forest model soil: $1.0 \times 10^{-2}, 5.0 \times 10^{-2}$ and $0.2 \mathrm{mg} \mathrm{kg}^{-1}$, all examined in triplicate. Sarin in the leachate was found on the $4^{\text {th }}$ day in a concentration below the exposure limit. That can be explained by the nature of the soil's relatively high $\mathrm{pH}$ (7.83) and high content of organic compounds (1.97\% by Turin's method) and microflora. It is well known that these factors accelerate sarin degradation. Therefore a LOAEC was not determined, and $0.2 \mathrm{mg} \mathrm{kg}^{-1}$, as the highest concentration of sarin, was used as the NOAEC value.

The study of sarin migration in air has shown that, as for other soil models, agent evaporates from the surface only within the first hour after contamination. The LOAEC and NOAEC of the agent were found to be 0.3 and $0.1 \mathrm{mg} \mathrm{kg}^{-1}$, respectively. 
It was found that sarin has a strong influence on the soil microbial community. For example, nitrification processes were more sensitive to sarin presence than was microbiome. The LOAEC and NOAEC were found to be $5.0 \times 10^{-2}$ and $1.0 \times 10^{-2} \mathrm{mg} \mathrm{kg}^{-1}$, respectively for the microbiome, and $3.0 \times 10^{-2}$ and $1.0 \times 10^{-2} \mathrm{mg} \mathrm{kg}^{-1}$, respectively, for nitrification processes. Therefore, $1.0 \times 10^{-2} \mathrm{mg} \mathrm{kg}^{-1}$ of sarin was chosen as the maximum allowable concentration for forest soil models.

Seed germination was studied at sarin concentrations of $2.0 \times 10^{-2}, 5.0 \times 10^{-2}, 0.1$ and $0.3 \mathrm{mg}$ $\mathrm{kg}^{-1}$, in triplicates. It was found that the two highest concentrations of sarin influenced beet root germination. Sarin, at the three highest concentrations, also showed significant inhibition of beet and wheat roots at $0.3 \mathrm{mg} \mathrm{kg}^{-1}$ on the $7^{\text {th }}$ day of the experiment. LOAEC and NOAEC concentrations of sarin for this criterion were $5.0 \times 10^{-2}$ and $2.0 \times 10^{-2} \mathrm{mg} \mathrm{kg}^{-1}$, respectively.

Vegetation experiments were performed with three different concentrations of sarin: $0.3,0.9$ and $2.7 \mathrm{mg} \mathrm{kg}^{-1}$. It was found that the highest concentration inhibits wheat development in the period from the $3^{\text {rd }}$ to $7^{\text {th }}$ day. The subsequent measurement of the average mass of the green part of the wheat (haulm cut directly before measurement) did not show any significant difference from the controls. Based on that, the LOAEC and NOAEC were taken as 2.7 and $0.9 \mathrm{mg} \mathrm{kg}^{-1}$, respectively.

Based on the lowest concentration above, the NOAEC of sarin on biome, the exposure limit for sarin in the forest soil model was found to be $1.0 \times 10^{-2} \mathrm{mg} \mathrm{kg}^{-1}$ (Table 4).

In summary, sarin has been found to be an ecotoxic hazard in different soil models. It is able to migrate from soil into the air and ground water and have a negative influence on the growth and development of higher plants, as well as the general microbial soil condition.

It should be noted that a research methodology was developed to determine the maximum allowable contamination of different types of soils by a highly toxic substance (sarin). For other types of soil, when a similar study cannot be conducted, the value $3 \times 10^{-4} \mathrm{mg} / \mathrm{kg}$ (measured for the standard reference soil in the extreme laboratory conditions) may be used and corrected for the type of soil and climate conditions of interest. 


\section{Conclusions}

It is concluded that: the introduction of sarin to different types of soils results in a significant adverse change in their ecosystem functions; the limiting indicators of sarin in soil are its migration in water for standard reference soil and the general health of soil constituents and plants for prairie and forest model soils, and that the maximum exposure limits of sarin in SRS, PSM and FSM are $3.0 \times 10^{-4}, 2.0 \times 10^{-3}$ and $1.0 \times 10^{-2} \mathrm{mg} \mathrm{kg}^{-1}$, respectively.

\section{Future Work}

Based on recent developments in Syria, it would be highly recommended that a similar study be performed on soil types typical to that part of the world.

\section{Acknowledgements}

The authors wish to thank the Global Partnership Program within the Government of Canada's Department of Foreign Affairs and International Trade for their financial support.

\section{References}

Agadzhanov, G.L. 1993. International agreements in the chemical disarmament and the problem of the safe destruction of chemical weapons, Russian Chemical Journal, 37(3) pp. 8-10.

Babeva, I.P. and Zenova, G.M., 1989. Soil biology, second ed., MSU. Moscow.

Center for Disease Control (CDC) 2015.

http://www.cdc.gov/niosh/ershdb/emergencyresponsecard_29750001.html 
Chemical weapons and problem of its destruction, 1996. The convention on the prohibition of chemical weapons. Problems of ratification, No. 2, pp. 5-9.

Egorenkov, L.I. and Kochurov, B.I. 2005. Geoecology, Finances and statistics, Moscow.

Egorova, E.I. and Belolipetskaya, V.I. 2000. Bioassay and bioindication of the environment: The study guide, OIATE, Obninsk.

Franke, S., Franz, P. and Warnke W. 1967. Lehrbuch der Militarchemie Band 1 Deutscher Militarverlag Berlin.

Goncharuk, E.I. and Sidorenko, G.I. 1986. Guide for the hygienic regulations of chemicals in the soil, Meditsina, Moscow.

Green, M.B., Hartley, G.S., and West, T.F. 1979. Pesticides and plant protection (Translated from English by P.V. Popov), Kolos, Moscow.

Guidance on the sanitary-microbiological study of soil, 1976. Gos. No. 1446-76.

Guidelines on the occupational exposure limits in soil, second ed., Gos. 1982, No 2609-82, pp.57

Hotuntsev, Y.L. 2004. Ecology and environmental safety, second ed., Academia, Moscow. 
Isidorov, V.A. 2001. Ecological chemistry, Chimizdat, St. Petersburg.

Kaurichev, I.S. 1982. Pedology, third ed., Kolos, Moscow.

Kaurichev, I.S. 1990. Practical training in pedology, Kolos, Moscow.

Korolev, V.A. 2001. Soil decontamination, Nauka, Moscow.

Kruglov, Y.V. 1991. Soil microflora and pesticides, Agropromizdat, Moscow

Lobova, E.V. and Khabarov, A.V. 1983. Soils (The nature of the world), Misl, Moscow.

Medscape 2015. http://emedicine.medscape.com/article/831648-overview\#showall

Melnikov, N.N., Volkov, A.I. and Korotkova, O.A., 1977. Pesticides and environment, Himiya, Moscow.

Methodological guidelines on methods of control. 2004. MUK 4.1.64 - 04. Methods for measuring of the mass concentration of sarin in bodies of drinking and household water by gas chromatography: Approved by chief state sanitary inspector of Russia 08.010.2004; replaced N791/6 from 15/04/1981. 
Mineev, V.G. and Rempe, E.K. 1990. Agricultural chemistry, biology and ecology of soil, Rosagropromizdat, Moscow.

Mineev, V.G., 2001. Practical training in agricultural chemistry, second ed., MSU, Moscow.

Mishustin, E.N., Pertsovskaya, and M.I. Gorbov, V.A. 1979. Sanitary soil microbiology, Nauka, Moscow.

Health and Safety Administration (OSHA), U.S. Department of Labor 2015.

https://www.osha.gov/SLTC/emergencypreparedness/guides/nerve_cwa_air_table_0803200 $\underline{4 . p d f}$

Office of Secretary of Defense, 2015. http://www.gulflink.osd.mil/dugway/low lv chem fact.htm

Organisation for the Prohibition of Chemical Weapons (OPCW) 2015.

https://www.opcw.org/chemical-weapons-convention/

http://www.opcw.org/news/article/the-opcw-prepares-for-historic-challenge/

https://www.opcw.org/news/article/opcw-executive-council-gravely-concerned-about-

continuing-use-of-chemical-weapons-in-syria/ and

https://www.opcw.org/news/article/director-general-circulates-opcw-ffm-reports-to-statesparties/

Pavlov, A.N. 2005. Ecology: Environmental management and life safety, Visshaya Shkola, Moscow. 
Protasov, V.F. 2005. Ecology, health and environmental protection in Russia, Finances and statistics, Moscow.

Revazova, A.Y. 2000. Modern approaches to the assessment of environment contamination by genotoxicants and genetic health of population, Thesis of the $2^{\text {nd }}$ Congress of the Vavilov society of geneticist and breeders, St. Petersburg, February 1-5, p. 204.

Sadovnikova, L.K. 2006. Ecology and environmental protection in the chemical contamination scenario, third ed., Visshaya Shkola, Moscow.

Serikoff, I.I. 1992., Investigation of genetic hazards: Guidance from occupational and environmental studies Popul. Proc. N.C., May 10-12.

Serikoff, I.I. 1994. Individ. Susceptibility Genotoxic Agents New-York; London, 1994. pp.1 - 20.

Shilov, I.A. 2006. Ecology, Visshaya Shkola, Moscow.

Slodkopevtsev, S.A. 2005. Land tenure and nature management, Visshaya Shkola, Moscow.

State Research Institute of Organic Chemistry and Technology (GosNIIOKhT). 2005. Method of sarin concentration measurement in the air of the working area by enzymatic analysis., N031-01-011-05 from 15/11/2005. 
Strelnikov, V.V. 2004. Ecological toxicology, KubGAU, Krasnodar.

UnitedNations (UN). 2013.

http://www.un.org/apps/news/story.asp?NewsID=46730\#.VyDG6Xrciro

Yudanova, L.A. 1989. Pesticides in the environment. Analytical review, GPNTB SO AN USSR, Novosibirsk.

Zvyagintsev, D.G. 1980. Methods in soil microbiology and biochemistry, MSU, Moscow, 
Table 1. Characteristics of the soil types

\begin{tabular}{|c|c|c|}
\hline & Canadian soils & Analogue Russian soils \\
\hline Soil location & Prairie & Steppe zone of the Lower Volga \\
\hline Soil description & $\begin{array}{l}\text { Brown calcareous, brown } \\
\text { semidesert low gypseous. The soil } \\
\text { profile is greyish-brown, powdery } \\
\text { humus horizon. }\end{array}$ & $\begin{array}{l}\text { Brown calcareous, brown steppe } \\
\text { low gypseous. The soil profile is } \\
\text { greyish-brown, powdery humus } \\
\text { horizon. }\end{array}$ \\
\hline $\mathrm{pH}$ & $7.0-12.0$ & $7.5-10.0$ \\
\hline $\begin{array}{l}\text { Humus content } \\
\qquad(\%)\end{array}$ & $1.2-3.0$ & $1.2-4.0$ \\
\hline Soil location & $\begin{array}{l}\text { Sod-calcareous soils of } \\
\text { deciduous and mixed forests }\end{array}$ & $\begin{array}{l}\text { Forest zone of the Republic of } \\
\text { Udmurtia }\end{array}$ \\
\hline Soil description & $\begin{array}{l}\text { Light gray and gray forest's } \\
\text { illuvium-humus-iron podzols with } \\
\text { residual carbonate. The soil is } \\
\text { loose, brownish-gray in color, } \\
\text { unstructured or with weak thin- } \\
\text { layer structure. Consists mainly of } \\
\text { sandy-loam. Sandy and loamy } \\
\text { soils are less common. }\end{array}$ & $\begin{array}{l}\text { Sod-carbonate and sod-podzolic } \\
\text { with residual carbonate soils of } \\
\text { brown color of different intensity. } \\
\text { Individual ashed lighter spots are } \\
\text { visible under the sod and topsoil } \\
\text { layer. Consists mainly of sandy- } \\
\text { loam. Sandy and loamy soils are } \\
\text { less common }\end{array}$ \\
\hline $\mathrm{pH}$ & $4.0-6.5$ & $5.5-6.5$ \\
\hline $\begin{array}{l}\text { Humus content } \\
\text { (\%) }\end{array}$ & $2.5-9.0$ & $2.5-7.5$ \\
\hline
\end{tabular}


Table 2. Experimentally determined lowest-observed-adverse-effect (LOAEC) and no-observedadverse-effect (NOAEC) concentrations of sarin in the standard reference soil (SRS)

\begin{tabular}{lcc}
\hline \multicolumn{1}{c}{ Hazard index } & $\begin{array}{c}\text { LOAEC of sarin in SRS, } \\
\mathrm{mg} \mathrm{kg}^{-1}\end{array}$ & $\begin{array}{c}\text { NOAEC of sarin in SRS, } \\
\mathrm{mg} \mathrm{kg}^{-1}\end{array}$ \\
\hline Translocation: & $2.5 \times 10^{-2}$ & $1.0 \times 10^{-2}$ \\
Germination & 0.1 & - \\
Root length & $2.5 \times 10^{-2}$ & $1.0 \times 10^{-2}$ \\
Migration in air & $5.0 \times 10^{-3}$ & $2.0 \times 10^{-3}$ \\
Migration in water & $5.0 \times 10^{-4}$ & $3.0 \times 10^{-4}$ \\
\hline
\end{tabular}


Table 3. Experimentally determined lowest-observed-adverse-effect (LOAEC) and noobserved-adverse-effect (NOAEC) concentrations of sarin in the prairie model soil (PMS)

\begin{tabular}{lcc}
\hline \multicolumn{1}{c}{ Hazard index } & $\begin{array}{c}\text { LOAEC of sarin in SRS, } \\
\mathrm{mg} \mathrm{kg}{ }^{-1}\end{array}$ & $\begin{array}{c}\text { NOAEC of sarin in SRS, } \\
\mathrm{mg} \mathrm{kg}^{-1}\end{array}$ \\
\hline General soil health: & $5.0 \times 10^{-3}$ & $\mathbf{2 . 0 \times 1 0 ^ { - 3 }}$ \\
Microbiome & 0.1 & $5.0 \times 10^{-2}$ \\
Nitrification & $5.0 \times 10^{-3}$ & $2.0 \times 10^{-3}$ \\
Translocation: & $1.0 \times 10^{-2}$ & $\mathbf{2 . 0 \times 1 0 ^ { - 3 }}$ \\
& - & $5.0 \times 10^{-2}$ \\
Germination & $1.0 \times 10^{-2}$ & $2.0 \times 10^{-3}$ \\
Root length & 0.45 & 0.15 \\
Vegetation & - & $\mathbf{0 . 1}$ \\
Migration in water & 0.1 & $\mathbf{5 . 0} \times \mathbf{1 0}^{-\mathbf{2}}$ \\
Migration in air & &
\end{tabular}


Table 4. Experimentally determined lowest-observed-adverse-effect (LOAEC) and noobserved-adverse-effect (NOAEC) concentrations of sarin in the forest model soil (FMS)

\begin{tabular}{lcc}
\hline \multicolumn{1}{c}{ Hazard index } & $\begin{array}{c}\text { LOAEC of sarin in SRS, } \\
\mathrm{mg} \mathrm{kg}{ }^{-1}\end{array}$ & $\begin{array}{c}\text { NOAEC of sarin in SRS, } \\
\mathrm{mg} \mathrm{kg}^{-1}\end{array}$ \\
\hline General health: & $3.0 \times 10^{-2}$ & $\mathbf{1 . 0} \times \mathbf{1 0}^{-\mathbf{2}}$ \\
Microbiome & $5.0 \times 10^{-2}$ & $1.0 \times 10^{-2}$ \\
Nitrification & $3.0 \times 10^{-2}$ & $1.0 \times 10^{-2}$ \\
Translocation: & $5.0 \times 10^{-2}$ & $\mathbf{2 . 0} \times \mathbf{1 0}^{-\mathbf{2}}$ \\
& & \\
Germination & 0.1 & $5.0 \times 10^{-2}$ \\
Root length & $5.0 \times 10^{-2}$ & $2.0 \times 10^{-2}$ \\
Vegetation & 2.7 & 0.9 \\
Migration in water & - & $\mathbf{0 . 2}$ \\
Migration in air & 0.3 & $\mathbf{0 . 1}$ \\
\hline
\end{tabular}


Table A1. Physico-chemical properties of the Standard Reference Soil (SRS)

Composition

- Particles with diameter $>0.1 \mathrm{~mm}, \%$

- Particles with diameter $<0.1 \mathrm{~mm}, \%$

- Maximum particle diameter, $\mathrm{mm}$

Moisture capacity, \%

$\mathrm{pH}$ of the aqueous extract of soil samples

Organic Carbon, $\%$

Ammoniacal Nitrogen, $\mathrm{mg} / \mathrm{kg}$

Nitrite-Nitrogen $\left(\mathrm{NO}_{2}{ }^{-}\right), \mathrm{mg} / \mathrm{kg}$

Nitrate-Nitrogen $\left(\mathrm{NO}_{3}{ }^{-}\right), \mathrm{mg} / \mathrm{kg}$

Mobile Phosphorus, mg/kg

Actinomycetes, $\times 1000$ cells per $1 \mathrm{~g}$ of soil

Micromycetes, $\times 1000$ cells per $1 \mathrm{~g}$ of soil

Saprophytic bacteria, $\times 1000$ cells per $1 \mathrm{~g}$ of soil

Escherichia Coli, $\times 1000$ cells per $1 \mathrm{~g}$ of soil
Sand

95.0

5.0

0.5

21.2

7.22

0.02

Not observed

Not observed

Not observed

Not observed

Not observed

Not observed

Not observed

Not observed 
Table A2. Physico-chemical properties of the forest soil model (FSM) from the Republic of Udmurtia and its mixture with Standard Reference Soil (SRS).

\begin{tabular}{|c|c|c|}
\hline & FSM & FSM : SRS $(1: 2)$ \\
\hline Mechanical Composition: & $\begin{array}{c}\text { Sand, Loam, } \\
\text { Organics }\end{array}$ & $\begin{array}{c}\text { Sand, Loam, } \\
\text { Organics }\end{array}$ \\
\hline Particles with diameter $>7 \mathrm{~mm}, \%$ & 19.70 & Not observed \\
\hline Particles with diameter $>4 \mathrm{~mm}, \%$ & 27.03 & Not observed \\
\hline Particles with diameter $>2 \mathrm{~mm}, \%$ & 32.10 & 12.50 \\
\hline Particles with diameter $>1 \mathrm{~mm}, \%$ & 9.73 & 7.40 \\
\hline Particles with diameter $>0.3 \mathrm{~mm}, \%$ & 7.53 & 27.80 \\
\hline Particles with diameter $<0.3 \mathrm{~mm}, \%$ & 2.30 & 15.80 \\
\hline Maximum particle diameter, $\mathrm{mm}$ & 2.0 & 0.3 \\
\hline Moisture capacity, \% & 55.21 & 27.75 \\
\hline $\mathrm{pH}$ of the aqueous extract of soil samples & 7.83 & 7.71 \\
\hline Organic Carbon, $\%$ & 1.97 & 0.55 \\
\hline RedOx potential Eh, $\mathrm{mV}$ & 334 & 295 \\
\hline Soil porosity, $\%$ & 56 & 46 \\
\hline Dry soil density, $\mathrm{g} / \mathrm{cm}^{3}$ & 2.59 & 2.47 \\
\hline Hydrolytic acidity, Eq/100 g soil & Not observed & Not observed \\
\hline Exchange acidity, Eq/100 g soil & 0.056 & 0.024 \\
\hline Hydrolytic alkalinity, Eq/100 g soil & 0.64 & 2.52 \\
\hline Ammoniacal Nitrogen, $\mathrm{mg} / \mathrm{kg}$ & 20.10 & 7.87 \\
\hline Nitrite-Nitrogen $\left(\mathrm{NO}_{2}^{-}\right), \mathrm{mg} / \mathrm{kg}$ & 0.621 & 0.55 \\
\hline Nitrate-Nitrogen $\left(\mathrm{NO}_{3}{ }^{-}\right), \mathrm{mg} / \mathrm{kg}$ & 2.13 & 1.66 \\
\hline Mobile Phosphorus, mg/kg & 33.82 & 17.14 \\
\hline Actinomycetes, $\times 1000$ cells per $1 \mathrm{~g}$ of soil & 433.47 & 243.17 \\
\hline
\end{tabular}


Micromycetes, $\times 1000$ cells per $1 \mathrm{~g}$ of soil

Saprophytic bacteria, $\times 1000$ cells per $1 \mathrm{~g}$ of soil

25.75

13.95

1755.73

997.34

Escherichia Coli, $\times 1000$ cells per $1 \mathrm{~g}$ of soil

57.15

23.41 
Table A3. Physico-chemical properties of the Canadian prairie soil model (PSM) from the Lower Volga region and its mixture with Standard Reference Soil (SRS).

\begin{tabular}{|c|c|c|}
\hline & PSM & PSM : SRS (4:1) \\
\hline Mechanical Composition: & $\begin{array}{c}\text { Sand, Loam, } \\
\text { Organics }\end{array}$ & $\begin{array}{c}\text { Sand, Loam, } \\
\text { Organics }\end{array}$ \\
\hline Particles with diameter $>7 \mathrm{~mm}, \%$ & 9.3 & Not observed \\
\hline Particles with diameter $>4 \mathrm{~mm}, \%$ & 7.7 & Not observed \\
\hline Particles with diameter $>2 \mathrm{~mm}, \%$ & 15.9 & 7.2 \\
\hline Particles with diameter $>1 \mathrm{~mm}, \%$ & 10.1 & 19.8 \\
\hline Particles with diameter $>0.3 \mathrm{~mm}, \%$ & 32.1 & 52.3 \\
\hline Particles with diameter $<0.3 \mathrm{~mm}, \%$ & 24.0 & 20.7 \\
\hline Maximum particle diameter, $\mathrm{mm}$ & 0.3 & 0.3 \\
\hline Moisture capacity, $\%$ & 52.56 & 42.19 \\
\hline $\mathrm{pH}$ of the aqueous extract of soil samples & 8.45 & 8.62 \\
\hline Organic Carbon, $\%$ & 1.2 & 0.59 \\
\hline RedOx potential Eh, $\mathrm{mV}$ & 288 & 261 \\
\hline Soil porosity, $\%$ & 54 & 48 \\
\hline Dry soil density, $\mathrm{g} / \mathrm{cm}^{3}$ & 2.69 & 2.57 \\
\hline Hydrolytic acidity, Eq/100 g soil & Not observed & Not observed \\
\hline Exchange acidity, Eq/100 g soil & 0.06 & 0.059 \\
\hline Hydrolytic alkalinity, Eq/100 g soil & 1.53 & 1.57 \\
\hline Ammoniacal Nitrogen, $\mathrm{mg} / \mathrm{kg}$ & 0.753 & 0.476 \\
\hline Nitrite-Nitrogen $\left(\mathrm{NO}_{2}^{-}\right), \mathrm{mg} / \mathrm{kg}$ & 0.122 & 0.105 \\
\hline Nitrate-Nitrogen $\left(\mathrm{NO}_{3}{ }^{-}\right), \mathrm{mg} / \mathrm{kg}$ & 1.755 & 1.68 \\
\hline Mobile Phosphorus, mg/kg & 28.3 & 24.24 \\
\hline Actinomycetes, $\times 1000$ cells per $1 \mathrm{~g}$ of soil & 203.47 & 153.47 \\
\hline
\end{tabular}


Micromycetes, $\times 1000$ cells per $1 \mathrm{~g}$ of soil

Saprophytic bacteria, $\times 1000$ cells per $1 \mathrm{~g}$ of soil

2.15

1.73

Escherichia Coli, $\times 1000$ cells per $1 \mathrm{~g}$ of soil

975.73

875.73

47.25

41.25 
Table A4. Concentrations of O-ethyl-S-(2-diisoproylaminoethyl) methyl

phosphonothiolate (sarin) in $\mathrm{mg} / \mathrm{kg}$ used for determination of LOAEC and NOAEC in soils.

\begin{tabular}{|l|c|c|c|}
\hline \multirow{2}{*}{ Experiment } & \multicolumn{3}{|c|}{ Soil Type } \\
\cline { 2 - 4 } & SRS & PSM & FSM \\
\hline Extraction by water & $\begin{array}{c}4 \times 10^{-4} ; 3 \times 10^{-4} ; 2 \times 10^{-4} \\
1 \times 10^{-4} ; 0.5 \times 10^{-4}\end{array}$ & $0.1 ; 0.05 ; 0.025$ & $0.2 ; 0.05 ; 0.01$ \\
\hline Migration to air & $2 \times 10^{-2} ; 5 \times 10^{-3} ; 2 \times 10^{-3}$ & $0.1 ; 5 \times 10^{-2} ; 5 \times 10^{-3}$ & $0.3 ; 0.1 ; 0.03$ \\
\hline Microbiology & & $0.1 ; 5 \times 10^{-2} ; 2.5 \times 10^{-2}$ & $0.3 ; 0.1 ; 0.05 ;$ \\
& & & $0.03 ; 0.01$ \\
\hline Nitrification & & $0.1 ; 0.05 ; 0.01 ; 5 \times 10^{-3} ;$ & $0.3 ; 0.1 ; 0.05 ;$ \\
& & $2 \times 10^{-3}$ & $0.03 ; 0.01$ \\
\hline Germination & $10 ; 1 ; 0.1$ & $0.05 ; 0.01 ; 0.002$ & $0.3 ; 0.1 ; 0.05$ \\
\hline Root length & $0.05 ; 0.025 ; 0.015$ & $0.05 ; 0.01 ; 0.002$ & $0.3 ; 0.1 ; 0.05 ;$ \\
& & & 0.02 \\
\hline Vegetation & & $0.45 ; 0.15 ; 0.05$ & $2.7 ; 0.9 ; 0.3$ \\
\hline
\end{tabular}

